\title{
PENGGUNAAN METODE RAPID APLICATION DEVELOPMENT (RAD) DALAM PEMBUATAN APLIKASI PELAPORAN KEAMANAN DAN KESELAMATAN LAUT
}

\author{
Indra Agustina ${ }^{1}$, Anita Ratnasari ${ }^{2}$ \\ ${ }^{1}$ Jurusan Sistem Informasi-Fakultas Ilmu Komputer/Universitas Mercubuana \\ Jl.Meruya Selatan No.1, Meruya Selatan, Kembangan, Jakarta Barat \\ 141817110026@student.mercubuana.ac.id, ${ }^{2}$ anita.ratnasari@mercubuana.ac.id
}

\begin{abstract}
Abstrak - Indonesia sebagai negara kepulauan (archipelagic state) terbesar di dunia yang terdiri dari 5.698 pulau bernama dan 11.801 pulau belum bernama. Sumber daya alam laut yang potensial memberikan banyak harapan serta kesejahteraan masyarakat dan juga penghasil industri maritim, seperti industri perikanan, wisata bahari, industri perkapalan dan jasa doking, jasa pelabuhan maupun sumber daya mineral serta energi. Dampak dari banyaknya aktivitas maritim akan menimbulkan kerawanan dan ancaman yang terjadi seperti pencurian, perampokan, penyelundupan, perusakan lingkungan hidup serta kecelakaan - kecelakaan dilaut. Sehingga dalam menjembatani pelaporan kejadian yang terjadi di laut dari masyarakat kepada Bakamla RI, masyarakat dapat memanfaatkan teknologi komunikasi yang ada saat ini seperti smartphone yang menjadi salah satu media yang dapat dimanfaatkan dengan menggunakan aplikasi mobile sebagai sarana dalam pelaporan atau penyampaian informasi. Kebutuhan masyarakat dalam memberikan laporan kejadian ataupun informasi yang terjadi di laut kepada Bakamla RI dapat terpenuhi.
\end{abstract}

Kata Kunci-Aplikasi mobile, Pelaporan, Sistem Informasi.

Abstract - Indonesia as the largest archipelago country (archipelagic nation) in the world which consists of 5,698 islands named and 11,801 islands not yet named. Marine natural resources that have the potential to provide a lot of hope and welfare of the people and maritimeproducing industries, such as the fishing industry, marine tourism, shipping industry, and docking services, transportation services and mineral and energy resources. The impact of maritime involvement will cause vulnerability and threats that occur such as theft, robbery, smuggling, environmental destruction and accidents at sea. It is possible to bridge the reporting of events that occur at sea from the public to Bakamla RI, the public can use existing communication technologies such as smartphones which are one of the media that can be utilized by using cellular applications as a means of reporting or delivering information. The needs of public in providing reports on events or information happening at sea to Bakamla RI can be fulfilled.

Keywords-Mobile Application, Reporting, Information System.

\section{PENDAHULUAN}

Indonesia sebagai negara kepulauan (archipelagic state) terbesar di dunia yang memiliki wilayah yang berbatasan langsung dengan sepuluh negara tetangga. Secara kewilayahan Indonesia memiliki luas memiliki 17.499 pulau yang terdiri atas 5.698 pulau bernama dan 11.801 pulau tidak/belum bernama [1].

Sehingga dapat diartikan bahwa Indonesia memiliki sumber daya alam (SDA) yang sangat potensial dan memberikan banyak harapan serta kesejahteraan masyarakat. Laut juga penghasil berbagai industri maritim, seperti industri perikanan, wisata bahari, industri perkapalan dan jasa doking, jasa pelabuhan maupun sumber daya mineral serta energy[2].
Dampak tersebut akan menimbulkan kerawanan dan ancaman yang terjadi di wilayah Indonesia, seperti adanya pencurian, perampokan, penyelundupan, perusakan lingkungan hidup serta kecelakaan yang ada dilaut baik tabrakan kapal, hilang kontak, kapal karam dan kapal tenggelam ditambah lagi dengan adanya alur kepulauan laut Indonesia sebagai jalur lalu lintas yang digunakan bagi kepentingan pelayaran lokal maupun internasional akan bertambah tinggi dampaknya. Dari data yang didapat dari Bakamla RI terlihat masih banyak kecelakaan yang terjadi di laut yang tersebar di seluruh Indonesia di bulan Juni 2019.

Indonesia dengan kepadatan lalu lintas pelayarannya pada jalur - jalur ALKI I, II dan III terutama pada selat Malaka ini terlihat dari citra satelit 
NASA Earth Obsevatory dari sebaran jumlah SOx Emisi kapal [3].

Dengan tingginya intensitas lalu lintas pelayaran di Indonesia tentu permasalahan keamanan dan keselamatan pengguna laut menjadi salah satu faktor yang sangat penting dalam menunjang kelancaran transportasi laut dan mencegah terjadinya kecelakaan. Dalam menjaga keamanan dan keselamatan di laut perlu adanya kerjasama antara pengguna laut dengan petugas yang berwenang untuk terciptanya keamanan dan keselamatan di laut dalam menyampaikan informasi kejadian di laut yang ditemui atau dialami para pengguna laut atau masyarakat maritim.

Badan Keamanan Laut Republik Indonesia dengan tugasnya melakukan patroli keamanan dan keselamatan di wilayah perairan Indonesia dan wilayah Yuridiksi Indonesia. Bakamla RI memiliki fungsi antara lain Menyusun kebijakan nasional di bidang keamanan dan keselamatan di wilayah perairan Indonesia dan wilayah yurisdiksi Indonesia, menyelenggarakan sistem peringatan dini keamanan dan keselamatan di wilayah perairan Indonesia dan wilayah yurisdiksi Indonesia, melaksanakan penjagaan, pengawasan, pencegahan dan penindakan pelanggaran hukum di wilayah perairan Indonesia dan wilayah yuridiksi Indonesia, menyinergikan dan memonitor pelaksanaaan patroli perairan oleh instansi terkait, memberikan dukungan teknis dan operasional kepada instansi terkait, memberikan bantuan pencarian dan pertolongan di wilayah perairan Indonesia dan wilayah yurisdiksi Indonesia dan melaksanakan tugas lain dalam sistem pertahanan nasional. Sehingga dalam menjembatani pelaporan kejadian yang terjadi di laut dari masyarakat kepada Bakamla RI, masyarakat dapat memanfaatkan teknologi komunikasi yang ada saat ini seperti smartphone yang menjadi salah satu media yang dapat dimanfaatkan. Dalam mengembangkan aplikasi maka akan dibuat aplikasi sebagai sarana dalam pelaporan atau penyampaian informasi. Dengan adanya aplikasi tersebut diharapkan dapat mewadahi masyarakat dalam memberikan laporan kejadian ataupun informasi yang terjadi di laut kepada Bakamla RI.

\section{METODE PENELITIAN}

Penelitian di lakukan pada markas besar Bakamla RI. Dengan informasi yang dimiliki Bakamla RI terkait keamanan dan keselamatan di laut, dapat diketahui bahwa tindak kejahatan maupun kecelakaan yang terjadi dilaut sering terjadi di beberapa wilayah saja, Oleh karenanya, dengan melihat informasi tindak kejahatan maupun kecelakaan di Bakamla RI, dapat diketahui kebutuhan Bakamla RI dalam mengumpulkan informasi tidak hanya diperoleh dari kantor - kantor Bakamla RI yang tersebar di seluruh wilayah Indonesia ataupun dari Opensource, melainkan informasi juga didapat dari masyarakat maritim atau pengguna laut.
Berikut adalah diagram alir penelitian sebagai panduan dalam melakukan penelitian ini :

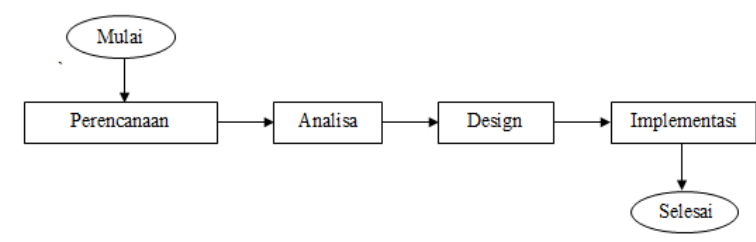

Gbr. 1 Diagram Alir Penelitian

\section{A. ANALISA}

Dalam menentukan kebutuhan system, peneliti melakukan analisis SWOT ditunjukkan pada Tabel I terhadap penyampaian laporan masyarakat di Bakamla RI dengan hasil analisis SWOT yang ditunjukkan pada Tabel II.

Metode analisis SWOT peneliti gunakan dalam memetakan kebutuhan aplikasi pelaporan yang akan dibuat. Analisis SWOT adalah alat yang digunakan untuk perencanaan strategis dan manajemen strategis dalam organisasi. Dapat digunakan secara efektif untuk membangun strategi organisasi dan strategi kompetitif [4]. Dalam analisis SWOT yang terdiri dari empat area menjadi dua dimensi. Komponen SWOT seperti 'Strengths', 'Weaknesses', 'Opportunities', 'Threats'. Strengths dan Weaknesses merupakan faktor internal sedangkan peluang dan ancaman merupakan faktor eksternal. Analisis SWOT biasanya dibuat dalam kotak empat kuadran yang memuat ringkasan disusun sesuai dengan empat judul bagian.

TABEL I

ANALISIS SWOT

\begin{tabular}{|l|l|}
\hline Strengths (Kekuatan) & $\begin{array}{l}\text { Menerima dan menindak lanjuti laporan semua kejadian yang } \\
\text { terjadi di laut dari masyarakat. }\end{array}$ \\
\cline { 2 - 3 } & $\begin{array}{l}\text { Pelapor memiliki kemampuan untuk menggunakan } \\
\text { smartphone. }\end{array}$ \\
\hline $\begin{array}{l}\text { Weaknesses } \\
\text { (Kelemahan) }\end{array}$ & $\begin{array}{l}\text { Dalam proses penyampaian informasi masih terbatas lisan } \\
\text { sehingga kurang lengkap data dukung kejadian dalam } \\
\text { melaporkan. }\end{array}$ \\
\cline { 2 - 2 } & $\begin{array}{l}\text { Pendataan laporan tidak didukung dengan sistem yang } \\
\text { terkomputerisasi dalam penyimpanan sehingga akan sulit } \\
\text { dalam melakukan pencarian laporan. }\end{array}$ \\
\hline $\begin{array}{l}\text { Opportunities } \\
\text { (Peluang) }\end{array}$ & $\begin{array}{l}\text { Dapat menerima laporan berbagai jenis kejadian yang terjadi } \\
\text { di laut. }\end{array}$ \\
\cline { 2 - 2 } & $\begin{array}{l}\text { Dibutuhkan suatu aplikasi dalam penyampaian laporan } \\
\text { kejadian yang terjadi di laut }\end{array}$ \\
\hline Threats (Ancaman) & $\begin{array}{l}\text { Laporan yang disampaikan akan berpotensi terjadinya laporan } \\
\text { palsu. }\end{array}$ \\
\cline { 2 - 2 } & $\begin{array}{l}\text { Dalam melakukan pencarian laporan akan mengalami } \\
\text { kesulitan. }\end{array}$ \\
\hline
\end{tabular}


TABEL II

HASIL ANALISIS SWOT

\begin{tabular}{|c|c|c|}
\hline Faktor Eksternal & Strength (Kekuatan) & Weakness (Kelemahan) \\
\hline Opportunity (Peluang) & $\begin{array}{l}\text { Perlunya dibuatkan } \\
\text { aplikasi mobile untuk } \\
\text { melaporkan kejadian } \\
\text { yang terjadi di laut. }\end{array}$ & $\begin{array}{lrr}\text { Dengan adanya } & \text { aplikasi } \\
\text { mobile laporan yang } & \text { diterima } \\
\text { akan tersimpan } & \text { dalam } \\
\text { database disertai } & \text { data } \\
\text { pendukung laporan } & \text { yang } \\
\text { disampaikan. } & & \end{array}$ \\
\hline Threats (Ancaman) & $\begin{array}{l}\text { Semua laporan kejadian } \\
\text { yang terjadi di laut akan } \\
\text { mudah untuk diverifikasi } \\
\text { maupun dalam pencarian } \\
\text { laporan yang diterima } \\
\text { melalui aplikasi mobile. }\end{array}$ & $\begin{array}{l}\text { Membuat laporan dengan data } \\
\text { - data yang benar dan mudah } \\
\text { didapat sehingga aakan } \\
\text { memudahkan dal am membuat } \\
\text { laporan kejadian. }\end{array}$ \\
\hline
\end{tabular}

\section{B. DESIGN}

Dalam tahapan design peneliti menggunakan metode pengembangan sistem Rapid Aplication Development (RAD) dan Unified Model Language (UML). Rapid Application Development (RAD) merupakan suatu metode pengembangan yang lebih cepat dan mendapatkan hasil dengan kualitas yang lebih baik dibandingkan dengan hasil yang dicapai dengan siklus yang terdahulu. Orientasi objek pada metode RAD untuk pengembangan sistem yang mencakup pengembangan perangkat dan perangkat lunak [5]. RAD muncul sebagai pelengkap dalam menanggapi kelemahan dari pengembangan waterfall dan variasinya, karena RAD menggabungkan teknik teknik khusus dan peralatan computer untuk mempercepat tahapan analisa, design dan implementasi sebagian dari system yang dikembangkan dengan cepat sehingga pihak pengguna dapat melakukan evaluasi serta tanggapannya [6] James Martin memperkenalkan RAD pertama kali di tahun 90-an. Dan metode ini James Martin percaya bahwa model RAD adalah model pengembangan aplikasi yang lebih fleksibel dan adaptif untuk mengubah kebutuhan pengguna dan memastikan kualitas sistem yang berkembang cepat dengan biaya minimal [7].

Dengan kemampuan RAD yang di yakini dapat mendukung proses pengembangan perangkat lunak yang cepat, akan tetapi dalam pelaksanaannya metode ini memiliki resiko seperti mengurangi skalabilitas system-level, mengurangi efisiensi waktu dan kekuatan dalam proses pengembangan sistem, serta jangka waktu yang singkat dalam pengembangan system akan berdampak pada kualitas perangkat lunak[7]. Selain hal tersebut RAD juga dapat menimbulkan masalah dalam mengelola kebutuhan pengguna. Karena sistem dikembangkan dengan cepat dan pengguna mendapatkan pemahaman yang lebih baik tentang teknologi informasi, harapan pengguna tentu akan secara dramatis meningkat dan persyaratan sistem dapat berkembang selama proyek [6].

Dalam penerapannya, metode RAD harus didukung oleh tim pengembang yang ahli dalam teknik pembuatan software tentu akan menghasilkan biaya pengembangan yang tinggi dan spesifikasi perangkat keras yang dibutuhkan [6]. Ada 4 komponen yang memainkan peran dalam RAD seperti CASE (Computer Aided Software Engineering) tools, JAD (Joint Application Development) Sessions, Bahasa pemrograman visual / generasi ke empat dan Code Generator [6]. Ada empat tahapan dari RAD yaitu : rencana kebutuhan (Planning Requirement), Perancangan (Design), Pembangunan (Construction), dan Pelaksanaan (Implementation). RAD dapat dilakukan dalam berbagai cara seperti Iterative Development, System prototyping, Throwaway Prototyping. Pada Iterative Development dengan cara memecah keseluruhan proyek menjadi beberapa versi yang di kembangkan secara berurutan. Kebutuhan yang sangat penting dan mendasar di gabungkan menjadi system versi yang pertama. Versi ini di kembangkan dengan cepat dengan proses metode waterfall yang sederhana dengan satu kali tahapan implementasi. Pengguna dapat memberikan tanggapan untuk dimasukkan kedalam versi system berikutnya. Dengan demikian kepentingan bisnis dapat terpenuhi. Kerugian dalam penggunaan cara iterative development ini terletak pada penggunaan system yang digunakan dalam versi awal dan pengenalan system yang berulang untuk versi sistem baru seperti terlihat pada Gbr 2 .

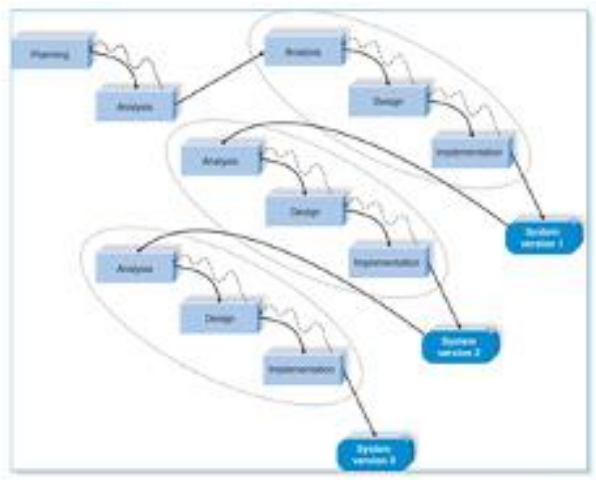

Gbr. 2 Model RAD dengan Iterative Development

System Prototyping melakukan tahapan analisis, desain, dan implementasi bersamaan untuk mengembangkan versi sederhana dari sistem yang diusulkan dan memberikannya kepada pengguna untuk dapat di evaluasi dan memberikan umpan balik dari versi tersebut.

System prototype memberikan versi prototipe pertama dengan fitur minimal, mengikuti reaksi dan komentar dari pengguna dapat di lihat pada Gbr 3.

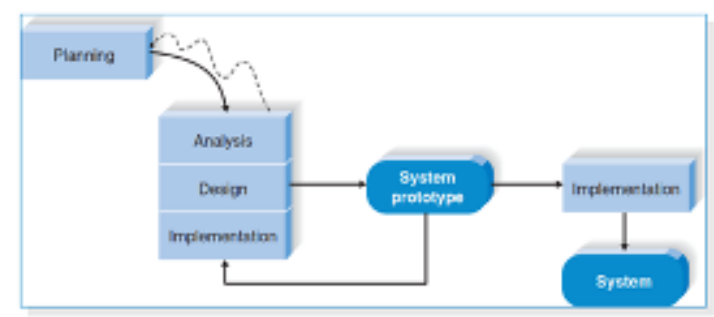

Gbr. 3 Model RAD dengan System Prototyping 
Pengembang melakukan analisa ulang, mendesain ulang, dan mengimplementasikan kembali versi prototipe kedua dengan memperbaiki kekurangan dan menambahkan lebih banyak fitur. Siklus ini berlanjut hingga analis, pengguna, dan sponsor sepakat hingga versi prototipe sudah menyediakan fungsionalitas yang cukup untuk dipasang dan digunakan dalam organisasi. Sistem prototipe sangat cepat menyediakan sistem bagi pengguna untuk mengevaluasi dan meyakinkan pengguna bahwa perkembangan kemajuan tersebut sedang dalam pengerjaan. Pendekatan ini sangat berguna ketika pengguna memiliki kesulitan mengungkapkan persyaratan kebutuhan untuk sistem. Namun, kerugiannya adalah kurangnya menganalisa metode utama dalam membuat perencanaan dan keputusan dalam menentukan implementasi. System Prototype mungkin harus memiliki beberapa batasan perencanaan yang mendasar hal tersebut merupakan hasil langsung dari kurangnya pemahaman tentang kebutuhan sistem yang sebenarnya sejak awal proyek.

Teknik berikutnya adalah Throwaway Prototyping, teknik ini termasuk dalam pengembangan prototipe, prototipe dalam teknik ini digunakan dalam mengeksplorasi alternative design dan tidak di masukan kedalam sistem yang baru. Teknik ini memiliki tahapan analisis yang cukup menyeluruh untuk mengumpulkan kebutuhan dan mengembangkan ide - ide konsep sistem terlihat pada Gb 4. Namun, banyak fitur yang disarankan oleh pengguna mungkin tidak dipahami dengan baik, dan mungkin ada masalah teknis yang sulit untuk dipecahkan.

Masing-masing masalah diperiksa dengan menganalisis, merancang, dan membangun prototipe desain. Prototipe desain tidak dimaksudkan sebagai sistem kerja. Ini hanya berisi detail untuk memungkinkan pengguna memahami masalah yang sedang dipertimbangkan [6].

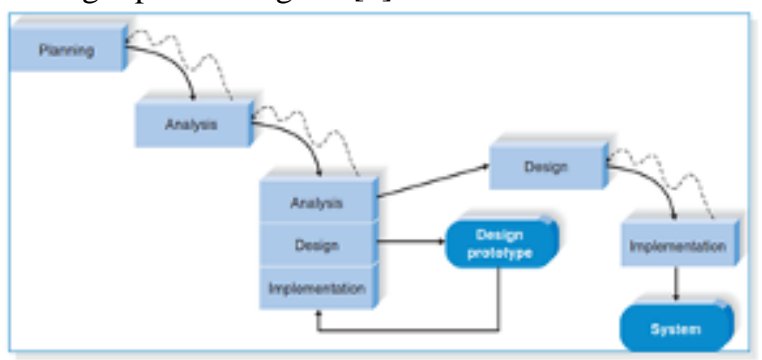

Gbr. 4 Model RAD dengan Throwaway Prototyping

Dalam melakukan perancangan sistem, peneliti menggunakan Unified Modeling Language (UML) yang terdiri dari use case diagram, class diagram untuk merancang database dan activity diagram untuk menjelaskan alur aktivitas

\section{IMPLEMENTASI}

Setelah perancangan aplikasi selesai dan disetujui oleh pengguna akhir, maka langkah selanjutnya untuk menjabarkan hasil perancangan ke dalam Bahasa pemrograman. Aplikasi yang sudah di buat sesuai dengan rancangan akan di lakukan pengujian oleh pengguna, dengan mencoba semua fitur yang ada dengan melakukan pengisian setiap input serta pengujian juga dilakukan dengan cara memastikan proses Create, Read, Update dan Delete (CRUD) telah berjalan dengan baik tanpa ada kendala.

Pengujian dengan metode black box dilakukan dengan melakukan masukan pada program aplikasi yang akan di proses untuk melihat apakah aplikasi pelaporan keamanan dan keselamatan laut dapat berjalan dengan optimal. Pengujian black-box ini digunakan untuk melakukan pengujian pada fungsi fungsi aplikasi yang dibuat dari hasil yang diuji hanya dilihat pada keluaran yang dihasilkan dari data atau kondisi masukan yang di berikan untuk fungsi yang ada tanpa melihat bagaimana proses untuk mendapatkan keluaran tersebut. Pada metode ini kesalahan yang ditemukan dalam kategori seperti fungsi tidak benar atau hilang, kesalahan antar muka, kesalahan pada struktur data (pengakses basis data), kesalahan inisialisasi dan akhir program dan kesalahan performansi [8].

\section{HASIL DAN PEMBAHASAN}

\section{A. USE CASE DIAGRAM}

Use Case Diagram digunakan untuk menggambarkan hubungan antara aktor dan sistem. Use Case Diagram merupakan penggerak utama semua teknik diagram UML berikut adalah Use Case Diagram dari aplikasi pelaporan keamanan dan keselamatan laut yang digunakan oleh Admin, Masyarakat dan Petugas seperti pada Gbr. 5.

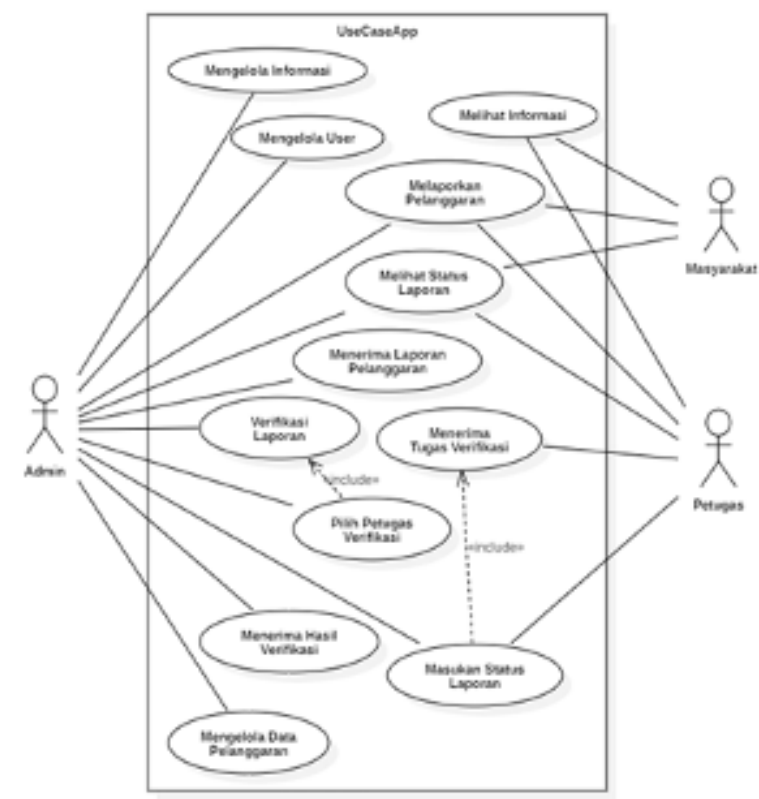

Gbr. 5 Use Case Diagram Sistem

\section{B. ACTIVITY DIAGRAM}

Diagram Activity adalah gambaran untuk memperlihatkan hubungan interaksi yang dinamis pada model sebelumnya dari suatu program [9]. Berikut adalah diagram activity pelaporan yang 
digunakan oleh pelapor dalam versi mobile, seperti pada Gbr. 6.

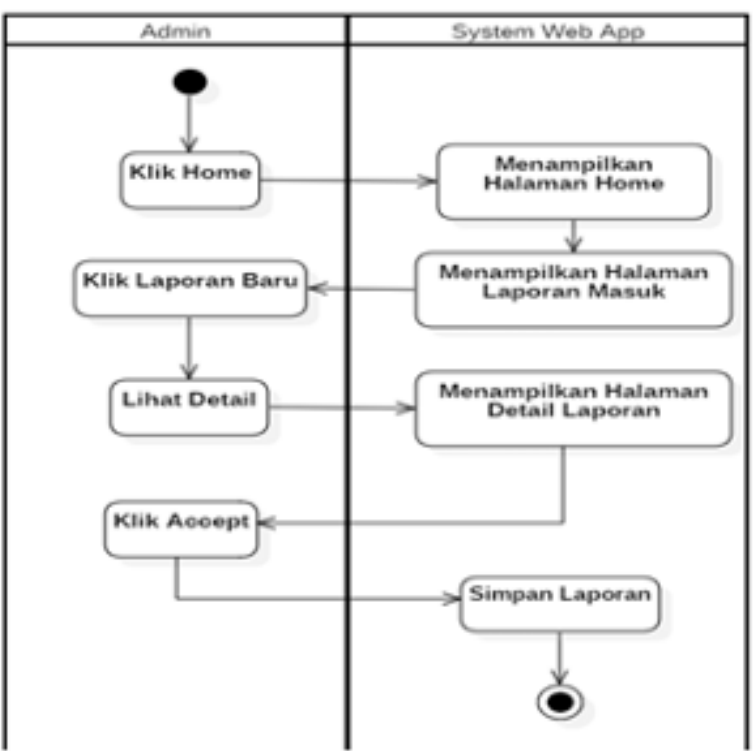

Gbr. 6 Diagram Activity Menerima Laporan Pelanggaran

\section{SEQUENCE DIAGRAM}

Diagram Sequence digunakan untuk melihat interaksi antar obyek yang digunakan sesuai dengan tahapan penggunaannya seperti pada Gbr 7 .

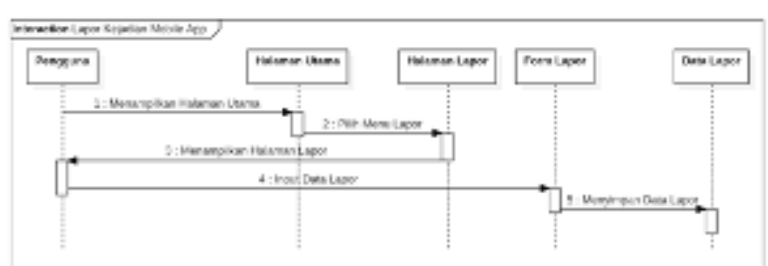

Gbr. 7 Diagram Sequence Melaporkan Kejadian Mobile

\section{CLASS DIAGRAM}

Class Diagram adalah kumpulan objek - objek yang memiliki struktur umum. Sebuah class digambarkan seperti sebuah bujur sangkar dengan tiga bagian ruangan. Class sebaiknya diberi nama menggunakan kata-kata benda sesuai dengan domain/bagian/kelompoknya seperti pada Gbr 7 .

\section{E. PERANCANGAN DATABASE}

Dalam perancangan basis data aplikasi pelaporan keamanan dan keselamatan laut, perancangan tersebut seperti pada Tabel III.

\section{F. OUTPUT IMPLEMENTASI}

1) Halaman Login : Merupakan halaman awal dari aplikasi sebelum masuk ke halaman utama seperti pada Gbr 8 .

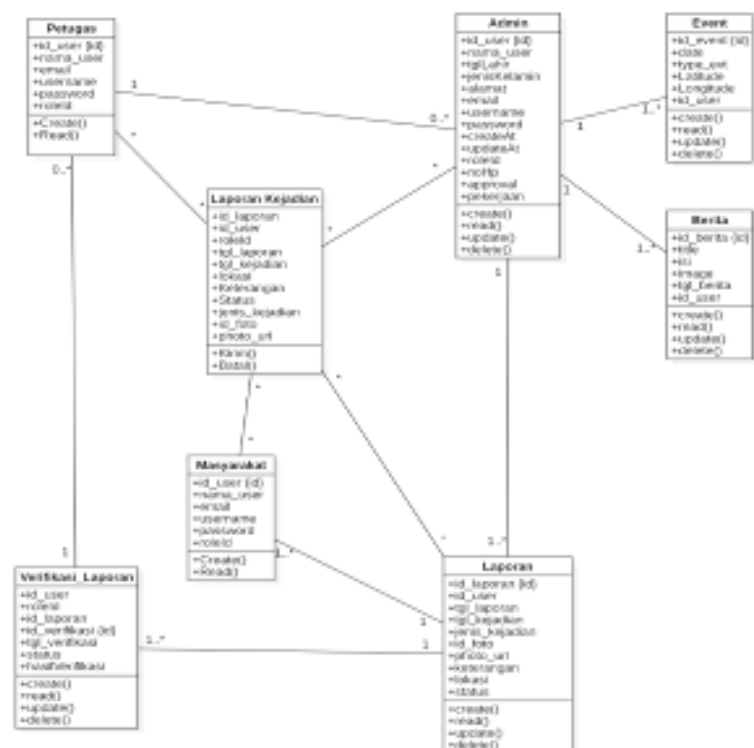

Gbr. 8 Class Diagram Aplikasi Pelaporan Keamanan dan Keselamatan Laut

TABEL IIII

RANCANGAN DATABASE APLIKASI PELAPORAN

\begin{tabular}{|l|l|l|}
\hline \multicolumn{1}{|c|}{ Field } & \multicolumn{1}{c|}{ Type } & Keterangan \\
\hline id_laporan & Varchar(13) & Primary Key \\
\hline id_user & Varchar(13) & \\
\hline tgl_laporan & Datetime & \\
\hline tgl_kejadian & Datetime & \\
\hline Jenis_kejadian & Varchar(13) & \\
\hline id_foto & Varchar(13) & \\
\hline photo_url & Varchar(100) & \\
\hline Keterangan & Text & \\
\hline Lokasi & Varchar(100) & \\
\hline
\end{tabular}

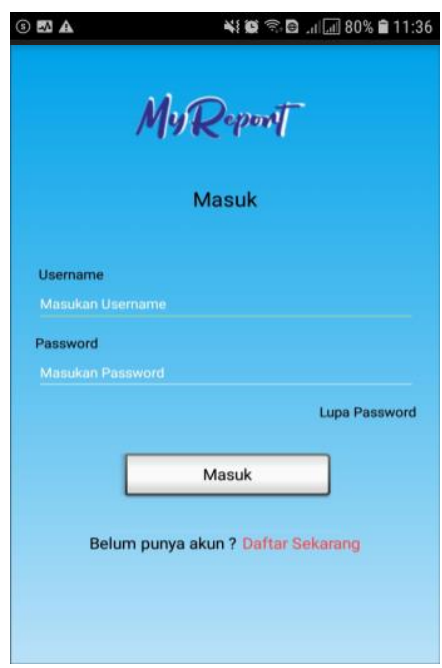

Gbr. 9 Halaman Login

2) Halaman Menu Utama : menampilkan menu utama jika user berhasil melakukan login. Pada menu utama ini user dapat melakukan memilih menu lapor, menu berita, menu status, menu peta, menu pesan, menu about, 
menu profil, home dan logout seperti pada Gbr 10 .

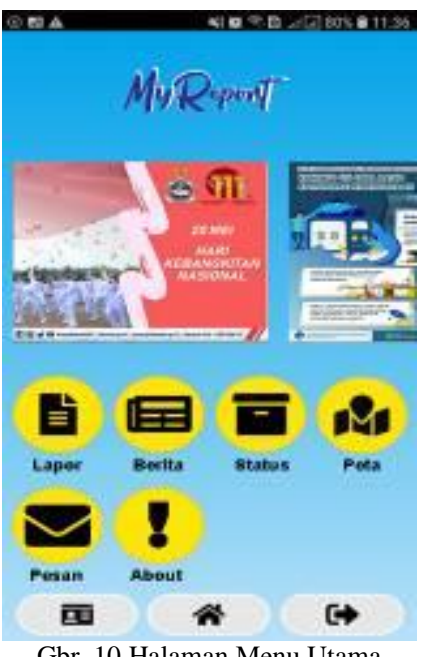

3) Halaman Menu Lapor : menampilkan menu lapor yang digunakan oleh user untuk mengirimkan informasi kejadian baik terkait keamanan maupun keselamatan di laut. Untuk mengirimkan informasi tersebut user harus mengisikan data - data yang disediakan seperti jenis kejadian, lokasi, keterangan dan user harus menyertakan foto sebagai data pendukung informasi seperti pada Gbr 11 .

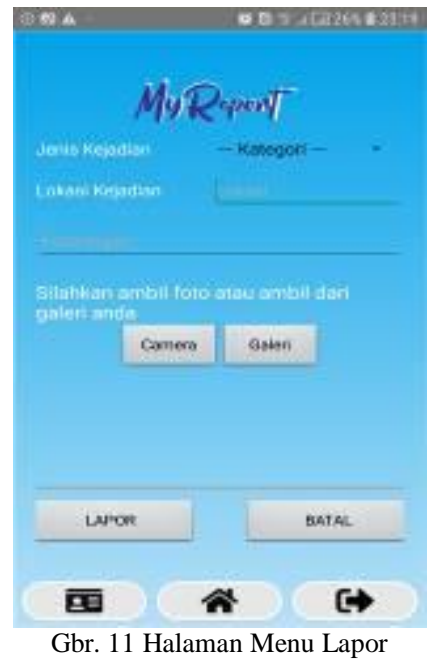

4) Halaman Menu Status : Menampilkan laporan / informasi yang sudah dikirimkan oleh user seperti tanggal, jenis kejadian, lokasi kejadian, keterangan dan status dari laporan apakah sudah "di terima", "di verifikasi” atau "di tindak lanjuti” seperti pada Gbr 11.

5) Halaman Menu Peta : menampilkan peta sebaran kejadian pelanggaran yang ada di sekitar pengguna seperti pada Gbr 12 .

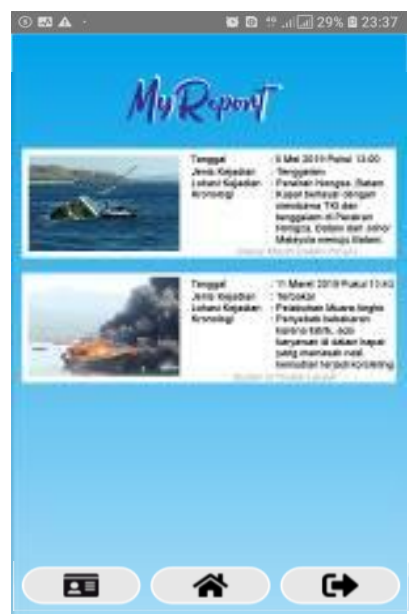

Gbr. 12 Halaman Menu Status

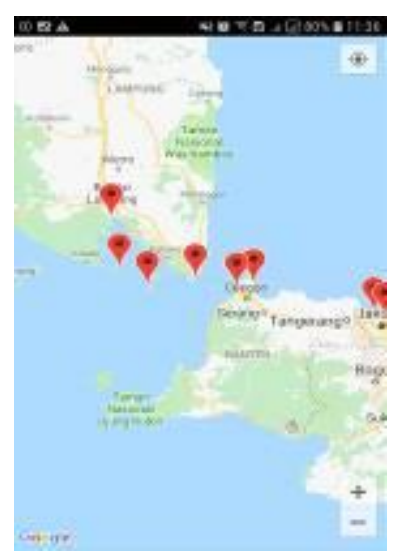

Gbr. 13 Halaman Menu Peta

\section{G. PENGUJIAN APLIKASI}

Untuk mengetahui apakah aplikasi dapat berjalan sesuai dengan yang diharapkan maka diperlukan pengujian.

TABEL IIIV

TABEL PENGUJIAN APLIKASI

\begin{tabular}{|c|c|c|c|}
\hline \multirow[t]{2}{*}{ No } & \multicolumn{3}{|c|}{ Test Procedure } \\
\hline & Verifikasi & Test Deskripsi & Hasil \\
\hline 1 & Halaman Login & $\begin{array}{l}\text { Pengecekan proses } \\
\text { input username dan } \\
\text { password }\end{array}$ & Success \\
\hline 2 & $\begin{array}{l}\text { Halaman Menu } \\
\text { Utama }\end{array}$ & $\begin{array}{l}\text { Pengecekan proses } \\
\text { menampilkan } \\
\text { halaman menu utama } \\
\text { beserta komponen } \\
\text { lainnya }\end{array}$ & Success \\
\hline 3 & $\begin{array}{l}\text { Halaman Menu } \\
\text { Lapor }\end{array}$ & $\begin{array}{l}\text { Pengecekan proses } \\
\text { menampilkan } \\
\text { halaman menu lapor } \\
\text { dengan menginputkan } \\
\text { form lapor dan } \\
\text { mengambil gambar }\end{array}$ & Success \\
\hline
\end{tabular}




\begin{tabular}{|c|c|c|c|c|}
\hline \multirow{3}{*}{ Page | 130} & & & $\begin{array}{l}\text { melalui kamera / } \\
\text { galeri }\end{array}$ & \\
\hline & 4 & $\begin{array}{l}\text { Halaman Menu } \\
\text { Status }\end{array}$ & $\begin{array}{l}\text { Pengecekan proses } \\
\text { menampilkan } \\
\text { halaman menu status } \\
\text { dari laporan yang } \\
\text { dikirimkan }\end{array}$ & Success \\
\hline & 5 & $\begin{array}{l}\text { Halaman Menu } \\
\text { Peta }\end{array}$ & $\begin{array}{l}\text { Pengecekan proses } \\
\text { menampilkan } \\
\text { halaman menu peta } \\
\text { disertai sebaran data } \\
\text { pelanggaran yang } \\
\text { sudah terjadi. }\end{array}$ & Success \\
\hline
\end{tabular}

\section{IV.PENUTUP}

Hasil dari penelitian penggunaan metode Rapid Application Development dalam pembuatan aplikasi pelaporan keamanan dan keselamatan laut memberikan hasil yang optimal sehingga dapat di digunakan oleh Bakamla RI dalam menerima laporan kejadian dari masyarakat. Untuk penelitian selanjutnya perlu penambahan fitur lokasi - lokasi kantor Bakamla RI, TNI AL, POLAIRUD, PSDKP, KSOP, Kantor SAR, BEA CUKAI dan instansi lainnya yang memiliki wewenang di laut, notifikasi berita baru, notifikasi pesan masuk, fasilitas chat antar pengguna, lokasi pelabuhan dan tempat pelelangan ikan, hal ini diperlukan untuk menambah informasi bagi para pengguna aplikasi ini.

\section{UCAPAN TERIMA KASIH}

Terima kasih kepada Ibu Anita Ratnasari yang telah memberikan supportnya dalam proses penyelesaian penelitian ini. Serta kepada seluruh personil Direktorat Data dan Informasi Bakamla RI atas dukungan dan motivasinya. Dan keluarga atas doa - doa nya dalam penyelesaian penelitian ini. Judul untuk ucapan terima kasih dan referensi tidak diberi nomor. Terima kasih disampaikan kepada Risanuri Hidayat yang telah meluangkan waktu untuk membuat template ini.

\section{REFERENSI}

[1] D. Hidayati, R. Herlambang, N. Jadid, N. N. Sa'Adah, N. Maulidina, and A. P. D. Nurhayati, "Potential of yellowfin tuna catch in East Java-Indian Ocean based on length frequency and age distribution," J. Phys. Conf. Ser., vol. 1040 , no. 1,2018

[2] G. W. Kumalasari, "Kebijakan Pengembangan Konsep Sea Gate International (Sgi) Guna Mewujudkan Kemandirian Maritim Indonesia,” vol. 24, no. 2, pp. 193 203, 2016.

[3] L. Johansson, J. Jalkanen, and J. Kukkonen, “A Comprehensive Modelling Approach for the Assessment of Global Shipping Emissions Global assessment of shipping emissions in 2015 on a high spatial and temporal resolution," Atmos. Environ., vol. 167, no. December, pp. 403-415, 2018.

[4] G. Emet, "SWOT ANALYSIS: A THEORETICAL REVIEW," J. Int. Soc. Res., vol. 10, no. 51, 2017.

[5] G. Wiro Sasmito and S. Wiyono, "Implementation of Rapid Application Development Method on Academic Staff System of Harapan Bersama Polytechnic," Int. J.
A. Dennis, B. H. Wixom, and R. M. Roth, System Analysis And Design, 5th ed. United States of America: John Wiley \& Sons, Inc, 2012.

[7] R. Delima, H. B. Santosa, and J. Purwadi, "Development of Dutatani Website Using Rapid Application Development," IJITEE (International J. Inf. Technol. Electr. Eng., vol. 1, no. 2, pp. 36-44, 2017.

H. Noprisson, Testing Dan Implementasi Sistem, no. 521. 2018.

[9] D. K. Kim, "Development of mobile cloud applications using UML," Int. J. Electr. Comput. Eng., vol. 8, no. 1, pp 596-604, 2018. 